\title{
The role of primary care in the prevention and control of healthcare associated infections*
} O PAPEL DA ATENÇÃO PRIMÁRIA NA PREVENÇÃO DE INFECÇÕES RELACIONADAS À
ASSISTÊNCIA À SAÚDE

\author{
EL ROL DE LAATENCIÓN PRIMARIA EN LA PREVENCIÓN DE INFECCIONES \\ RELACIONADAS CON LAASISTEN CIAA LA SALUD
}

Maria Clara Padoveze ${ }^{1}$, Rosely Moralez de Figueiredo²

\begin{abstract}
Little research has been conducted to date on the role of primary health care (PHC) in the prevention of healthcare associated infections (HCAls). The present article is a theoretical study of the principle of primum non nocere and aims to promote reflection on the role of PHC in HCAl prevention with emphasis on practical recommendations. The indirect and direct roles of PHC in HCAI prevention are debated in light of this guiding principle. With respect to the indirect role of PHC, we discuss the issues of hospital-centrism and ambulatory care-sensitive conditions. The article outlines a number of challenges faced by health services related to PHC's direct role in HCAI prevention, highlights seven key components of HCAl prevention programmes within the PHC sphere and provides practical recommendations for $\mathrm{HCAl}$ control and prevention.
\end{abstract}

\section{DESCRIPTORES}

Cross infection

Patient safety

Primary Health Care

Community health nursing

Models theoretical

\section{RESUMO}

O papel da Atenção Primária à Saúde (APS) na prevenção de Infecções Relacionadas à Assistência à Saúde (IRAS) é raramente discutido na literatura. O presente artigo tem por objetivo desenvolver um estudo teórico com base no princípio Primum non nocere, trazendo à luz uma reflexão sobre o papel da APS na prevenção de IRAS com ênfase nas recomendações de práticas. Os papéis indireto e direto da APS na prevenção de IRAS são debatidos, considerando este princípio orientador. No papel indireto da APS, discutem-se a questão do hospitalocentrismo e as internações por condições sensíveis à atenção primária. Referente ao papel direto apontam-se os desafios a serem superados. São indicados sete componentes essenciais para desenvolvimento de um programa de prevenção de IRAS na APS e respectivas recomendações.

DESCRITORES
Infecção hospitalar
Segurança do paciente
Atenção Primária à Saúde
Enfermagem em saúde comunitária
Modelos teóricos

\section{RESUMEN}

El rol de la Atención Primaria a la Salud (APS) en la prevención de Infecciones Relacionadas con la Asistencia a la Salud (IRAS) rara vez se discute en la literatura. El presente artículo tiene como meta desarrollar un estudio teórico con base en el principio Primum non nocere, trayendo a la luz una reflexión acerca del papel de la APS en la prevención de IRAS con énfasis en las recomendaciones de prácticas. Los roles indirecto y directo de la APS en la prevención de IRAS se debaten teniendo en cuenta este principio orientador. En el rol indirecto de la APS se discuten el tema del hospitalocentrismo y los internamientos por condiciones sensibles a la atención primaria. Con respecto al rol directo se apuntan los retos a superarse. Se señalan siete componentes esenciales para el desarrollo de un programa de prevención de IRAS en la APS y las respectivas recomendaciones.

\author{
DESCRIPTORS \\ Infección hospitalaria \\ Seguridad del paciente \\ Atención Primaria de Salud \\ Enfermería en salud comunitaria \\ Modelos teóricos
}




\section{INTRODUCTION}

The Declaration of Alma-Ata defines primary health care $(\mathrm{PHC})$ as

essential health care based on practical, scientifically sound and socially acceptable methods and technology made universally accessible to individuals and families in the community through their full participation and at a cost that the community and country can afford to maintain at every stage of their development in the spirit of self-reliance and self-determination(1).

PHC is considered a key element of healthcare and should not be understood as the antithesis of hospital care, but rather as an integrated response at all levels of the health system ${ }^{(2)}$.

Health systems must meet ever-increasing performance expectations and, according to the World Health Organisation (WHO), unsafe care is one of the five common limitations of healthcare services ${ }^{(2)}$. Minimizing the occurrence of healthcare associated infections (HCAls) is therefore a priority for assuring safe care.

The concept of patient safety is the absence of preventable harm to a patient during the process of health care $^{(3)}$, which is based on the axiom primun non nocere, which means first, do no harm, often attributed to Hippocrates, but whose real origin is unknown ${ }^{(4)}$. This is the motto of the principle of nonmaleficence which is directly tied to patient safety. Primun non nocere has been widely used and debated as a guiding principle of hospital care since the publication of the classic study undertaken by the Institute of Medicine (IOM) in the United States which highlighted that approximately 98,000 people die every year in the country as a result of medical errors ${ }^{(5)}$. However, although some studies suggest that this principle is applied to nonhospital care ${ }^{(6)}$, there is apparently little adherence to this principle in the PHC sphere.

The present article consists of a theoretical study of the Primum non nocere principle and aims to analyse patient safety within the PHC sphere focusing on the prevention of HCAl. We attempt to promote a reflection on the role of PHC in the prevention and control of HCAl, question to what extent the current care model embodies this guiding principle, and identify the main challenges and key components of a practical approach to HCAI prevention within the primary health care context.

\section{Study Development}

The focus of this study is the application of the principle primun non nocere in fulfilling the direct and indirect roles of PHC in the prevention of HCAls.

$\mathrm{PHC}$ is a pivotal component of the health system and plays an indirect role in HCAl prevention given that its core function is disease prevention and, consequently, the avoidance of unnecessary hospital admissions. PHC should also assure timely access to health services according to health needs. Unnecessary health interventions may cause harm, which is clearly opposed to the ethical precept embodied in the safety principle and adopted worldwide within the healthcare context ${ }^{(7)}$.

Ambulatory care-sensitive conditions (ACSCs) are used as markers to indicate quality of primary care ${ }^{(8-9)}$. A study carried out in the State of Minas Gerais showed an association between ACSCs and lack of follow-up in the Family Health Strategy (Estratégia Saúde da Familia - ESF) ${ }^{(9)}$. The authors highlight the major potential of ESF teams in the prevention of chronic diseases, which are the main causes of preventable admissions. The prevention of AC$\mathrm{SCs}$, which are the main causes of HCAl, leads to a natural reduction in exposure. The primun non nocere precept should therefore be firmly embedded in ACSCs prevention strategies, since merely preventing healthcare-associated harm is not enough: health promotion is necessary ${ }^{(4)}$.

The phenomenon known as hospital-centrism gives disproportional emphasis to resolving health problems through hospital care. Centralising hospital care implies considerable costs related to medication and iatrogenesis. From hospitalcentric perspective, when an individual is admitted to hospital, the general belief is that the unintended harm or suffering arising from any aspect of health care are directly related to the quality of care delivery. This is a simplistic view of the care process which fails to consider potentially relevant issues involving the relationships between the different levels of healthcare including: the actual need for hospital admission; whether adequate treatment of the condition could avoid the need for hospitalisation; and, where hospitalisation is really necessary, whether the patient is assured timely access to hospital care or if delays in medical attention lead to complications that could have been avoided? The avoidability of a condition is also related to prehospital care. This situation is often aggravated in the case of emergency surgeries, attending traumas and deliveries where any delay in care increases the likelihood of infection.

The exaggerated centralisation of medical care under the interventionist approach results in the excessive use of technology and technicality, where an increase in the number of tests and sophisticated patient assessments are seen as improvements in care and the adverse effects of invasive tests are often ignored. There is an induced lack of awareness of the fact that primun non nocere assumes a careful deliberation of when and when not to intervene and the possible harm caused by therapeutical or assessment procedures ${ }^{(10)}$. The strict meaning of primun non nocere within the PHC sphere can be found in the concept of quaternary prevention, which seeks to avoid harm caused by excessive medical care ${ }^{(7,10)}$. The excessive use of technology and technicality is linked to economic interests, given that certain sectors of the health industry have a vested interest in offering more lucrative services such as invasive procedures.
The role of primary care in the prevention and control of healthcare associated infections Padoveze MC, de Figueiredo RM 
Apart from effective care for ACSCs and timely access to care, PHC should provide and use a referral and counter-referral system and contribute towards post discharge follow-up of HCAls. From the continuity of health care perspective, PHC must encompass the detection and reporting the contraction of HCAls in other care service facilities. This is relatively common, especially in surgical site infections, and particularly after caesarean sections, and is generally only detected after discharge ${ }^{(11)}$. Another potential contribution is through monitoring the dispersal of bacteria resistant to antimicrobial agents, given that the dissemination of bacteria from health facilities to the community is possible ${ }^{(12-14)}$. The dissemination of bacteria resistant to antimicrobial agents is particularly relevant to the primun non nocere principle, given that associated risk factors include age extremes and chronic diseases, such as kidney failure, and that PHC plays an essential role in the care of these individuals ${ }^{(13-14)}$.

PHC is the level of care that is best placed to empower individuals and families, and promote awareness of rights related to health care and engagement in the care process, the latter of which is currently considered an important element of HCAI prevention ${ }^{(2,7)}$.

PHC should ideally be capable of offering personalised primary care to individuals and families that responds to their specific health needs. Community health should involve the whole life cycle, combat the determinants of diseases, and involve people as partners in the management of their illness and of the health of the community ${ }^{(2)}$. Although the first do no harm principle is embedded in the concept of PHC, it is necessary to broaden the perspective of patient safety and realise that safety begins before an individual is admitted to hospital.

Little research has been conducted to date on the direct role of PHC in HCAl prevention. The magnitude of adverse effects related to healthcare worldwide is underestimated. According to the $\mathrm{WHO}^{(2)}$, approximately one in every 10 patients in industrialised countries suffers from preventable harm and adverse effects related to his or her care, and it is likely that this number is even greater in developing countries ${ }^{(15)}$.

The traditional term hospital infections has given way to HCAI which reflects a widening of the concept to include infections acquired in different healthcare settings, regardless of where care is delivered ${ }^{(16)}$. This creates the need to provide information regarding preventive measures to health professionals working in other levels of care, other health staff, such as carers, and even to patients' families.

However, important differences exist between hospitals and other healthcare settings in terms of risk of infection and recommendations for prevention and control. Despite this, few agreed guidelines for the prevention and control of HCAl in nonhospital settings exist ${ }^{(6,17-18)}$.
Nonhospital care varies greatly in nature and includes a diverse range of settings, including dialysis centres, ambulatory surgery centres, doctors' and dentists' surgeries, physiotherapy centres and mental health centres. PHC finds itself within this context and is the main focus of this study.

Primun non nocere evokes reflection on quality expectations within $\mathrm{PHC}$ and on the following statement made by the WHO: it is not acceptable that, in low-income countries, primary care would be synonymous with low-tech, non-professional care for the rural poor who cannot afford any better ${ }^{(2)}$.

Little research has been conducted on the current approaches and challenges of HCAI prevention based on the principle of primun non nocere under Brazil's current healthcare model. The following text discusses specific challenges within the PHC system in Brazil.

a) Difficulties in defining HCAls: the adoption of targeted prevention measures should be based on evidence of factors that need be controlled or eliminated, which in turn requires epidemiological studies and well-defined criteria for determining diagnostic accuracy of HCAls. However, epidemiological studies of bacterial populations in settings other than dialysis centres and ambulatory surgery centres are scarce. Rare cases generally address outbreaks ${ }^{(16)}$ and an epidemiological surveillance system for HCAI within PHC has yet to be created. One of the obstacles to creating such a system are the conceptual difficulties involved in identifying episodes of HCAls associated with PHC procedures and the lack of resources available for accurate diagnosis. The diagnostic criteria for surveillance of HCAl in traditional hospital settings generally address acute admissions services ${ }^{(19)}$. One of the essential criteria for determining whether an infectious process is a HCAl is that the disease was not present at the time of treatment. However, chronicity in patients and recurrences are limiting factors for determining when an infection was acquired ${ }^{(12)}$ because, although care is continuous over time, each contact is brief. Furthermore, asymptomatic infectious processes may already exist at the time of care. In addition, comorbidities, such as HIV, that are prone to opportunistic infections hinder the clear definition of the disease as HCAl among this group. A reliable standardised denominator and indicators to facilitate process monitoring have yet to be produced ${ }^{(20)}$. The denominator person-time at risk, or alternatively, the number of cases per person may be used, while the use of the denominator people at risk apparently does not take into account this type of healthcare.

Apart from difficulties inherent in the PHC process, the lack of complementary diagnostic tools means that the diagnosis of HCAls in PHC settings is mainly based on signs and symptoms. This not only reduces the accuracy of the epidemiological and clinical diagnosis, but also leads to the excessive use of antibiotics, increasing selective pressure in a population of bacteria and potentially contributing towards resistance to antimicrobial agents. 
As a result, surveillance systems involving patients not admitted to hospital are often time consuming or lack sensitivity and specificity ${ }^{(20)}$. So how is it possible to measure the extent of harm resulting from HCAls in PHC settings if they cannot be clearly detected? The implementation of a sensitive, specific and efficient HCAI surveillance system is therefore a major challenge. Such a system should be simple and pragmatic and focus on the most likely preventable infections associated with the most common care procedures ${ }^{(12)}$.

b) Multidisciplinarity: a number of different types of professionals are involved in $\mathrm{PHC}$ in Brazil, including community health agents, dentists, nutritionists, pharmacists, social workers, nurses, physiotherapists, physicians, nurse technicians, and psychologists. The education and training of these professionals does not necessarily include the control and prevention of HCAls, and therefore certain professionals may not consider HCAls a potential problem. There is also a tendency towards detached care practices, in which professionals apply prevention measures based on individual knowledge rather than on standardised treatments.

Apart from problems related to immunisation, little is known about the risks involved with the most common care procedures in PHC. Procedures with a relatively significant level of invasiveness and which may result in adverse effects commonly performed in PHC include colpocitological tests, insertion of intrauterine devices, cervical cauterization, measurement of capillary blood glucose, inhalation, dressings, and injections. However, estimates regarding the adverse effects caused by such procedures do not exist. With respect to dental procedures, while there is a recognised risk associated with the acquisition of viruses such as hepatitis B and HIV, reports of HCAls caused by bacteria are rare.

The current literature provides little or no information regarding the potential risk of infection associated with physiotherapy, except in cases of hydrotherapy ${ }^{(20)}$. As a general rule, it is assumed that the risk associated with psychologists, nutritionists, social workers, and other professionals that do not use invasive procedures is minimal. However, the use of toys, special items of furniture and other devices may act as a reservoir for pathogens if they are not made with easily cleanable and disinfectable material.

In PHC healthcare facilities and settings it is rare to find trained professionals who are formally responsible for creating and implementing policy and provide training, supervision and guidance regarding HCAl control and prevention measures.

c) Rapid response needs: recent influenza pandemics clearly revealed the need for rapid response and highlighted the importance of an harmonious response organised between the different levels of healthcare. With regard to humanitarian disasters and disease outbreaks, it is vital that the health system is prepared to provide a rapid response.
To effectively react to a problem and provide adequate individual care and appropriate guidance to the population regarding prevention, PHC services must be staffed with properly trained and experienced professionals.

\section{A practical approach to the principle of primun pon nocere: key elements of HCAl prevention in PHC}

The national literature gives no clear indication on how a HCAl prevention and control programme for $\mathrm{PHC}$ should be structured and implemented, and few recommendations are provided regarding out-of-hospital care in general ${ }^{(12,17-18)}$. The main objective is to protect the patient, health workers and all other individuals in the physical healthcare environment and the public sector should provide the necessary financial resources for the implementation, maintenance and supervision of effective $\mathrm{HCAl}$ prevention in PHC settings. Eight key components can be highlighted and should be part of any set of measures implemented within the PHC sphere.

1. Standard precautions (SPS): SPs are a set of best practices for prevention that should be adopted with all patients, regardless of suspected diagnosis or confirmed infection $^{(21)}$. Adherence to SPs is widely recognised as the primary strategy for HCAl prevention ${ }^{(21)}$. The following procedures relevant to $\mathrm{PHC}$ are worth highlighting:

Hand hygiene: this is considered the most effective measure for preventing infections since it prevents the propagation of microorganisms in all care settings(22). Currently, the use of alcohol-based hand sanitizers on clean hands is preferred and these should be readily available in the care facility. The use of alcohol based products to clean the hands as opposed to washing with soap and water is preferred for a number of reasons: a) alcohol is more effective as a germicide; b) the antimicrobial action of alcohol is quicker; c) alcohol-based products dry the skin less. Alcohol gel dispensers are recommended in the reception of the health facility to promote hand hygiene among service users on arrival and during waiting. Hand hygiene should be performed during home visits and professionals should always carry alcohol-based hand gel with them.

Care with health products: there are two categories of health products: reusable and disposable ${ }^{(23)}$. The latter, for example syringes, needles and plastic vaginal speculum, should be disposed of and their reuse is unacceptable from a safety perspective and is not justifiable from a costbenefit point of view. With regard to reusable items, the relevant recommendations and norms regarding their use and reuse should be complied with ${ }^{(23-24)}$.

PHC procedures that present the greatest risk are those that involve the invasion of normally sterile tissues such as injections, venipuncture, vesical probing and certain dental procedures. The items used during these procedures should therefore be sterile. Procedures involving contact with mucous (dental procedures in general,
The role of primary care in the prevention and control of healthcare associated infections Padoveze MC, de Figueiredo RM 
colpocitological tests, dressings, and inhalation) present lesser risk, because mucous membranes provide certain protection against pathogenic invasion. In such cases, high level disinfection is required to ensure that microorganisms which are not part of the local microbiota do not penetrate this tissue and that pathogens are not transferred from one patient to the other.

Use of personal protective equipment (PPE): PPE consists of gloves, facial masks (common surgical masks), eye protection, and impermeable gowns that should be readily available in the care facility and used in case of contact with blood or when splashes or sprays of blood/body fluids are expected ${ }^{(21)}$.

Respiratory etiquette: patients should be advised to cover their nose and mouth when coughing or sneezing and perform subsequent hand hygiene. To facilitate this behaviour, paper tissues and hand hygiene products should be provided in treatment and waiting areas ${ }^{(21)}$.

Caring for the physical environment: it is the public sector's responsibility to provide adequate facilities and equipment for the effective running of primary healthcare centres $^{(25)}$ and ensure their regular maintenance ${ }^{(25)}$. All furniture, equipment and toys should be made of cleanable and disinfectable materials. Mattresses and mats used for physiotherapy, relaxation or other physical activities should be cleaned between each use.

Waste management: infectious waste requires specific treatment in accordance with relevant legislation. The healthcare team should be fully aware of what constitutes infectious waste ${ }^{(21)}$ and special attention should be given to sharps waste. Activities which frequently generate devices or objects used to puncture or lacerate the skin include vaccinations, dressings, blood and bodily fluid sampling, testing for blood glucose levels, and administration of medications. The areas where these activities are carried out should obligatorily contain special disposal units in accordance with relevant regulations: improvised bins to dispose of these items are unacceptable. Healthcare waste management related to home care is the responsibility of the health professional that provides care and waste items should be returned to the health facility for correct disposal and devices or objects used to puncture or lacerate the skin should be placed in a hard container carried by the professional.

2. Specific precautions: these comprise additional recommendations that should be followed when SPs do not suffice to interrupt transmission of pathogens ${ }^{(21)}$. There are three categories of specific precautions: contact precautions; droplet precautions; and airborne precautions ${ }^{(21)}$. Health conditions treated in PHC settings that most commonly require the adoption of specific precautions include: pulmonary tuberculosis, varicella (airborne), influenza (droplets), and scabies and multiresistant microorganisms (contact). Although treatment of these cases may be brief, it is vital to define specific procedures to prevent the transmission of these pathogens. Patients suspected to have such diseases should not wait for treatment in waiting areas and should be given priority treatment using the personal protective equipment recommended for each specific precaution ${ }^{(21)}$. During the contagious period, patients should be advised to use personal items and should not handle items that are for general use.

3. Care with medication and use of immunobiological products: medications and immunobiological products should be stored in washable containers under hygienic conditions, in a dry place, never in direct contact with the floor and stacked according to the manufacture's recommendations. Cardboard boxes should be disposed of since they are not hygienic and attract insects. Specific items should be stored in a temperature-controlled refrigerator specifically used for these products. Nonrelated items (food stuffs, organic material, etc...) should not be stored together in the same refrigerator. Hand hygiene products should be readily available in the storage and distribution area. Injections should be given safely with rigorous application of the aseptic technique. The use of multi-dose vials has been frequently associated with outbreaks of infections, especially those caused by the hepatitis $B$ and $C$ viruses and gram-negative bacteria ${ }^{(16,20,26)}$.

4. Occupational health: occupational health programmes for health workers are obligatory ${ }^{(27)}$ and should encompass accidents with potentially hazardous biological agents, provide for a well-managed flux of urgent treatments and vaccination in accordance with the $\mathrm{Na}$ tional Immunisation Programme, which includes hepatitis $B$, varicella and annual influenza vaccination.

5. Continuing education: all health professionals should receive training and take the necessary precautions to prevent infections ${ }^{(16)}$. Written routines and continuing education are vital for professionals to internalise a sense of responsibility and adhere to the principle of primum non nocere and foster patient and worker safety. At least one professional in a PHC facility should have advanced knowledge and experience of prevention and control of HCAls ${ }^{(12)}$. This professional should act as a link and facilitate the creation of standards and receive, interpret and manage reporting of adverse events in PHC. According to a panel of Canadian specialist, this professional should receive regular support from a specialist in control and prevention of infections and have access to laboratory resources to manage special cases ${ }^{(28)}$. Since the size of many primary health care centres does not justify the employment of one professional exclusively dedicated to this role, the creation of a specialised team is recommended to coordinate HCAl prevention and control among various centres in the same region.

6. Audits: periodic audits should be carried out by trained professionals using appropriate tools to ensure that best care practices are being adopted ${ }^{(6,16-18)}$. 
7. Rapid response: during epidemics, professionals trained in HCAl prevention and control should guide, enable and supervise measures for limiting risks, focusing on prevention measures directed at patients, families and health professionals, with effective coordination between $\mathrm{PHC}$ services and other services involved in the health surveillance system.

8. Patient engagement: knowledge of potential risks and effective communication with health professionals facilitates patient engagement in HCAl prevention. Patient engagement is a priority since it is a key to creating a safe environment and generates confidence in the health provider $^{(3)}$. However, this process requires a change in attitudes of health professionals and a care model which promotes patient participation in treatment decision-making and assures patient safety ${ }^{(29)}$. This includes providing information to patients about the relevant risks, benefits and uncertainties related to both diagnostic and therapeutic interventions. Furthermore, evidence-based healthcare

\section{REFERENCES}

1. Centro Latino-Americano e do Caribe de Informação em Ciências da Saúde; Biblioteca Virtual em Saúde. DeCS - Descritores em Ciências da Saúde. Atenção Primária à Saúde [Internet]. São Paulo; 2014 [citado 2014 set. 9]. Disponível em: http://decs.bvs.br

2. Organização Mundial de Saúde. Relatório Mundial de Saúde 2008. Cuidados de Saúde Primários: agora mais que nunca. Lisboa: Ministério da Saúde; 2008.

3. World Health Organization. Patient Safety [Internet]. Geneva; 2004 [cited 2013 Mar 3]. Available from: http://www.who.int/ patientsafety/about/en/index.html

4. Smith CM. Origin and uses of primum non nocere: above all, do no harm! J Clin Pharmacol. 2005;45(4):371-7.

5. Leape LL, Berwick DM. Five years after to err is human. JAMA. 2005;293(19):2384-90.

6. Centers for Diseases Control and Prevention. Guide to infection prevention for outpatient settings: minimum expectations for safe care [Internet]. Atlanta, GA; 2014 [cited 2014 June 26]. Available from: http://www.cdc.gov/HAl/settings/ outpatient/outpatient-care-guidelines.html

7. Tovar-Bobo M, Cerecedo-Pérez MJ, Rozadilla-Arias A. Éticay prevención de la medicalización. Semergen. 2013;39(7):376-81.

8. Malta DC, Duarte EC. Causas de mortes evitáveis por ações efetivas dos serviços de saúde: uma revisão de literatura. Ciênc Saúde Coletiva. 2007;12(3):765-76.

9. Fernandes VBL, Caldeira AP, Faria AA, Rodrigues Neto JF. Internações sensíveis na atenção primária como indicador de avaliação da Estratégia Saúde da Família. Rev Saúde Pública. 2009;43(6):928-36. should be patient-centred, and therefore a new conceptual model to guide research is vital ${ }^{(30)}$.

\section{FINAL CONSIDERATIONS}

The premises of Brazil's Unified Health System are congruent with the principle of primun non nocere and in line with the general understanding that preventable harm can no longer be tolerated. Despite this, Brazil's current healthcare model does not give due emphasis to strengthening the role (indirect and direct) of PHC in ensuring patient safety. The present study aimed to broaden the perspective of HCAl prevention and highlight important questions that deserve further research in the nursing field in order to overcome the challenges outlined by this study. The practical approach proposed by this study could provide a useful contribution to the development of guidelines that provide comprehensive recommendations for preventing HCAl within PHC settings.

10. Cucalón JM, Guiu M. El enigma de la prevención cuaternaria en atención primaria. Cuándo hacer y cuándo no hacer (a propósito de 2 casos). Semergen. 2013;39(6):313-5.

11. Cardoso Del Monte MC, Pinto Neto AM. Postdischarge surveillance following cesarean section: the incidence of surgical site infection and associated factors. Am J Infect Control. 2010;38(6):467-72.

12. Friedman C, Banette M, Buck AS, Ham R, Harris J, Hoffman $P$, et al. Requirements for infrastructure and essential activities of infection control and epidemiology in out-of-hospital settings: a consensus panel report. Infect Control Hosp Epidemiol. 1999;20(10):695-705.

13. Mielke M. Prevention and control of nosocomial infections and resistance to antibiotics in Europe - Primum non-nocere: elements of successful prevention and control of healthcare-associated infections. Int J Med Microbiol. 2010;300(6):346-50.

14. Gastmeier P. Healthcare-associated versus community-acquired infections: a new challenge for science and society. Int J Med Microbiol. 2010;300(6):342-5.

15. Allegranzi B, Bagheri Nejad S, Combescure C, Graafmans W, Attar H, Donaldson L et al. Burden of endemic health-care-associated infection in developing countries: systematic review and meta-analysis. Lancet. 2011;377(9761):228-41.

16. Kuehm BM. CDC targets health-related infections acquired in outpatient settings. JAMA. 2011;306(11):1189-90. 
17. Infection Control Nurses Association. Department of Health. Audit tools for monitoring infection control guidelines within community settings 2005 [Internet]. [cited 2011 Dec 14]. Available from: www.icna.co.uk

18. National Institute for Health and Clinical Excellence. Infection prevention and control of healthcare-associated infections in primary and community care [Internet]. London: Royal College of Physicians, UK; 2012 [cited 2014 June 26]. Available from: guidance.nice.org.uk/cg139

19. Centers for Disease Control and Prevention. CDC/NHSN surveillance definition of healthcare-associated infection and criteria for specific types of infections in the acute care setting [Internet]. Atlanta; 2008 [cited 2014 June 26]. Available from: https://www.premierinc.com/safety/topics/guidelines/downloads/surve-definitions-hospital.pdf

20. Nihill DM, Lundstrom T. Infection prevention and control in the outpatient setting. In: Laugntenbach $\mathrm{E}$. Infection control and epidemiology. 3rd ed. Washington: SHEA; 2010. p. 356-72.

21. Siegel JD, Rhinehart E, Jackson M, Chiarello L; Healthcare Infection Control Practices Advisory Committee. 2007 Guideline for Isolation Precautions: preventing transmission of infectious agents in healthcare settings [Internet]. Atlanta; 2007 [cited 2014 June 26]. Available from: http://www.cdc. gov/hicpac/pdf/isolation/isolation2007.pdf

22. Martín-Madrazo C, Salinero-Fort MA, Cañada-Dorado A, Carrillo-De Santa-Pau E, Soto-Díaz S, Abánades-Herranz JC. Evaluación del cumplimiento de higiene de las manos en una área de Atención Primaria de Madrid. Enferm Infec Microbiol Clin. 2011;29(1):32-5.

23. Costa EAM, Costa EA, Graziano KU, Padoveze MC. Medical device reprocessing: a regulatory model proposal for Brazilian hospitals. Rev Esc Enferm USP. 2011;45(6):1459-65.
24. Rutala WA, Weber DJ; Healthcare Infection Control Practices Advisory Committee. CDC Guideline for disinfection and sterilization in healthcare facilities 2008 [Internet]. Atlanta; 2008 [cited 2013 Feb 2]. Available from: http://www.cdc. gov/hicpac/pdf/guidelines/disinfection_nov_2008.pdf

25. Brasil. Ministério da Saúde; Secretaria de Atenção a Saúde, Departamento de Atenção Básica. Manual de estrutura física das Unidades Básicas de Saúde. 2ª ed. Brasília; 2008.

26. Maki DG, Crnich CJ. History forgotten is history relived: nosocomial infection control is also essential in the outpatient setting. Arch Intern Med. 2005;165(22):2565-7.

27. Brasil. Ministério da Saúde. Ministério do Trabalho e Emprego. Norma Regulamentadora n. 32 - Segurança e Saúde no Trabalho em Serviço de Saúde [Internet]. Brasília; 2005 [citado 2013 fev. 2]. Disponível em: http://portal.mte.gov. $\mathrm{br} /$ data/files/8A7C816A350AC8820135161931EE29A3/NR32\%20(atualizada\%202011).pdf

28. Morrison J; Health Canada, Nosocomial and Occupational Infection Section. Development of a resource model for infection prevention and control programs in acute, long term, and home care settings: conference proceedings of the Infection Prevention and Control Alliance. Am J Infect Control. 2004;32(1):2-6.

29. Longtin Y, Sax H, Leape LL, Sheridan SE, Donaldson L, Pittet D. Patient participation current knowledge and applicability to patient safety. Mayo Clin Proc. 2010;85(1):53-62.

30. Rich EC. From methods to policy: Primum non nocere: reconciling patient-centered outcomes with evidence-based care. J Comp Eff Res. 2013;2(2):107-8.

\section{Financial support}

The State of São Paulo Research Foundation (FAPESP, acronym in Portuguese). Application number 2010/16729-1. 